\title{
Modernite, Gürültü ve Sessizlik: Sosyolojik Bir Eleştiri
}

Modernity, Noise, Silence: A Sociological Critique

Mehmet TAN*

D 0000-0003-0398-9961

\section{MAKALE BILGİSI}

Başvuru: 17. 05. 2021

Düzeltme Talebi: 04. 06. 2021

Son Düzeltme: 17. 06. 2021

Kabul: 29. 07. 2021

Online Yayım: 15. 08. 2021

\section{Anahtar Kelimeler:}

Gürültü

Sessizlik

Gürültünün Sosyolojisi

Popüler Kültür

Modernite
ÖZ

Gürültü, insanları rahatsız eden ve onlar üzerinde olumsuz etkiler bırakan her türlü ses olarak bilinmektedir. Gürültünün toplumlara göre farklı anlamlar taşıdığı ve bu durumun sosyolojik olarak değerlendirilme gerekliliği öne çlkmaktadır. Bu çalıșma sosyal bir olgu olarak gürültünün insan ve onun yaşadığı toplum üzerindeki etkilerine odaklanmaktadır. Modern dünyanın bir temsili olarak kentler; kalabalık nüfuslar, farklı kültürel topluluklar, trafik sesleri gibi gürültü olaylarına sahne olmaktadır. Bu anlamda kentsel alanların sessiz kalma gibi bir lüksü olmadığı gibi sessizliğe erișim de oldukça maliyetli ve zor olabilmektedir. Ayrıca günümüz toplumunda öne çıkan popüler kültür ve müzik gürültünün önemli kaynakları arasında yer almaktadır. Müzikteki ses ve ritim bir hareketlilik sağlarken gürültüyü de onaylayabilmektedir. Müziğin yüksek ses ile dinlenilmesi ve giderek elektronikleşmesi gürültünün müzik alanında kullanıldığını göstermektedir. Gürültü, toplumsal hayatı etkilediği gibi kişilerarası ilișkilere de yansımaları olabilmektedir. Gürültünün, sosyal ilişkilere olumsuz etkileri olmakla birlikte bir iletişim tarzı olarak da kullanılabilmektedir. Çalıșma, teorik olarak gürültünün toplumsal hayattaki yerini ve etkisini tartışmaktadır. Sonuçta sosyal bir olgu olarak gürültüye atfedilen anlamlar onun modern dünyanın bir paradoksu olduğunu göstermektedir. Zira bir taraftan modern dünya gürültüyü artırırken ve onaylarken diğer taraftan gürültünün neden olduğu olumsuzlukları kabul etmekte ve bazen çözümler üretme çabasına girmektedir.

\section{ARTICLE INFO}

Submitted: 17. 05. 2021

Revision Requested: 04. 06. 2021

Final Revision Received: 17. 06. 2021

Accepted: 29. 07. 2021

Published Online: 15. 08. 2021

\section{Keywords:}

Noise

Silence

Sociology of Noise

Popular Culture

Modernity

\section{A B S T RACT}

Noise is known as any sound that disturbs and negatively affects people. It is seen that noise has different meanings according to societies, and this situation should be reviewed sociologically. This study focuses on the effects of noise as a social phenomenon on people and their societies. Cities represent the modern world; crowded populations, different cultural communities, are the scene of noise events such as traffic sounds. In this sense, urban areas do not have the luxury of staying silent, and access to silence can be quite costly and challenging. In addition, popular culture and music that stand out in today's society are among the significant noise sources. While the sound and rhythm in music provide activity, it can also confirm noise. The loudness of the music and its increasing electronification show that noise is used in music. Noise affects social life, as well as can have reflections on interpersonal relationships. Although noise has adverse effects on social relations, it can also be used as a communication style. The study theoretically discusses the place and impact of noise in social life. After all, the meanings attributed to noise as a social phenomenon show that it is a paradox of the modern world. While the contemporary world increases the volume of noise, it also accepts its adverse effects and tries to find solutions to minimize such effects.

\footnotetext{
${ }^{*}$ Yazar İletişim/ Corresponding Author: Mehmet Tan (Dr. Öğr. Üyesi), Siirt Üniversitesi, Fen Edebiyat Fakültesi, Sosyoloji Bölümü, Siirt, Türkiye 凶mehmet.tan@siirt.edu.tr

Kaynak Gösterimi/ Citing This Article: Tan, M., (2021). Modernite, gürültü ve sessizlik: Sosyolojik bir eleştiri. Sosyolojik Bağlam Dergisi, 2(2), 107-118. Doi: 10.52108/2757-5942.2.2.7
} 


\section{$1 \quad$ Giris}

Modern dünya, ekonomik, kültürel, siyasi, teknolojik vb. alanlarında yașanan gelișmelerle hızla değişmektedir. Özellikle teknolojik alanda yaşanan değişimlerin hızı adeta takip edilememektedir. Hızlı kentleşme, ulaşım araçlarındaki artış, insan kalabalıkları, teknolojik aygıtların yaygınlaşması gibi bazı faktörler toplumsal hayat açısından olumsuzluklara neden olabilmektedir. $\mathrm{Bu}$ olumsuzluklar arasında gürültü kirliliği de yer almaktadır. Gürültü, temelde insanlara rahatsızlık veren bir özellik taşımaktadır. Bu durum gürültünün tanımlarına yansımaktadır. Güler ve Çobanoğlu, (1994:12) gürültüyü "insan ve toplum üzerinde olumsuz etki yapan ve istenmeyen sesler" ve "belirgin bir yapısı olmayan, içerdiği öğelerle kişiyi bedensel veya psikolojik olarak etkileyebilen ses düzeni olarak" tanımlamaktadır. Gürültü, insan sağlığını ve psikolojisini olumsuz etkilerken insanların hayat kalitesine yönelik de olumsuz izler bırakmaktadır.

Pek çok olumsuzluğuna rağmen gürültü, sosyal hayatta varlığını devam ettirmektedir. Aslında, gürültünün, modern dünyanın bir temsili olduğunu söylemek mümkündür. Bu çerçevede modern olanın makbul olması gibi modern dünyada gürültü yaygınlaşmaktadır. Gürültüyü modernlikle ilişkilendirmek, gürültünün zaman içerisinde yeni anlamlar kazanması anlamına gelmektedir. Ayrıca toplumdan topluma, kültürden kültüre gürültü ve sessizliğe yüklenilen anlamlar değişebilmektedir. Bu durum, gürültünün bir sosyal olgu olarak ele ele alınmasını ortaya çıkarmaktadır. Gürültü, insan ürünü olması ve insanlara olan etkisi bağlamında toplumsal bir olgudur. Burada iletişim boyutuyla, söyleyişteki belirsizlik, konuşmadaki dikkatsizlik ve kötü üslup, önyargılı yaklaşım ile bilginin aktarılmasının engellenmesi gürültü olarak değerlendirilmektedir. Ayrıca bazı toplumsal hareketlerin, belirsizlik, düzensizlik ve ortaya çıkış nedenlerinin bilinmemesi de toplumsal gürültü olarak değerlendirilmektedir (Zafer ve Vardarlıer, 2019: 381-382).

Modern dünya içerisinde gürültü ile yaşamak vaka-i adiyeden sayılmaktadır. Geleneksel yaşamda ve teolojik düşüncede ise sessizlik, anlamlı ve hikmetli bulunmasına karşın gürültü olumsuz bir içeriğe sahiptir. Gürültü ve sessizliğin bu tezatlığı modern hayat içerisinde farklı şekillerde karşımıza çıkmaktadır. Gürültünün boş zaman aktivitelerinde ve eğlence dünyasında kullanılması sık karşılaşılan bir durum iken kimi zaman sessiz bir tatil olarak sakin tatil köyleri talep edilen bir durum olabilmektedir. Bu çerçevede gürültünün ontolojisi onaylanırken, gürültüden kaçış için açık kapı bırakılması da maliyetli bir sessizliğin ortaya çıkmasını sağlamaktadır. Berman (2016: 27) modern olmak, kendimizi ve dünyayı dönüştürme gücüne vaat etmesine rağmen her şeyi yok etmekle tehdit eden bir durumda olmayı da sağladığını vurgulamaktadır. Modernliğin bu tezat durumu gürültü ve sessizlik için de geçerli olabilmektedir.

Modern dünyada sosyal ilişkiler gürültü çerçevesinde yeniden şekillenmektedir. Gürültü, iletişimi kesen bir yönü olmasının yanı sıra bir iletişim tarzı olarak da kullanılmaktadır. İnsanların sesini etkin kullanarak karşı tarafı sindirerek haklı bir konum elde etmeye çalışması, gürültünün etkin iletişimde bir araç olarak kullanımını sağlamaktadır. Ayrıca gürültülü ortamlar kişilerarası ilişkilerde jest ve mimiklerin kullanımını sağlaması açısından gürültü, farklı iletişim kanallarının denenmesini sağlamaktadır. İnsanların seslerinin duyulamaması ya da anlaşılamaması kaygısı onlar için iletişimde bir sorun olduğunu göstermekte ve çözüm olarak insanlar, el hareketleri ve yüz mimikleri ile iletişimi güçlendirmeye çalışmaktadır.

Modern dünyanın görünür olduğu yerler kentlerdir. Kentler ise giderek gürültü ile özdeşleşmeye başlamaktadır. Kentlerin bazı sokak, cadde ve meydanları gürültü ile anılırken, alternatif olarak bazı sokak ve parklar sessizliğin mekânları olarak bilinmektedir. Kent, kendisinden kaynaklı gürültüye rağmen kendi içerisinde kısmi bir sessizlik oluşturmak kaydıyla çözümler üretebilmektedir. Gürültüden uzak, sakin ve huzurlu yaşamların vaat edildiği yerler, sessizliği tercih eden insanlar için bir çare ve seçenek olarak kabul görmektedir. 
Gürültünün sosyal hayatın bir parçası haline gelmesi insanların gürültüye alışmasını sağlamaktadır. Gündelik hayat içerisinde yaşanılanlara ve hissedilenlere bakıldığında gürültünün her alanda olduğu hatta yaşam tarzımıza yansıdığı görülebilmektedir. Örneğin özel alanınız olan evinizde iken, komşularınızın gürültüsü veya dışarıdan gelen müzik sesleri ya da bir satıcının bağırmasını duyabilirsiniz. Bunların yanı sıra kamusal alana çıktığınızda, araba sesleri, mağazalarda gelen müzik sesleri, insan kalabalıklarından gelen sesler vb. ile gürültüden izole kalmanın mümkün olmadığını anlarsınız. Çalışma, gürültüyü sosyolojik bir perspektifle ele almakta, modern dünyanın özelliklerinden hareketle gürültünün yaygınlığını ve gürültünün sosyal ilişkilere ve davranışlara etkisini tartışmaktadır. Bu bağlamda gürültü, modern dünyada olumlanırken ortaya çıkardığı kirlilik nedeniyle de rahatsızlıklara neden olabilmektedir. Modern dünyada gürültü paradoksal olarak var olmaya devam ederken popüler kültürde ve müzikte olumlanmaktadır.

\section{Gürültü ve Sessizlik Sosyolojisinin İmkânı}

Gürültü bir toplumsal gösterge olmasının yanı sıra gündelik hayatı biçimlendirme bağlamında kültürel pratiklerin ve genel olarak toplumların sınıflandırılmasının bir göstergesi olarak da ele almak mümkündür. "Sessiz" kutupta Amerikalı yerli halkaların pratikleri yer alırken, "gürültü" kutbuna yakın olarak Akdenizli milletlerin pratikleri yer alır. Bunlar yazma biçimleriyle ilgili, gelenek ve adetler tarafından tanımlanan farklılıklardır. Gürültülü kutba yakın olanların daha dışa dönük, ortak yaşamcı ve genellikle daha şenliklidir (Blandier, 2018: 40-41). Bu bağlamda bazı toplumların gelenek ve adetleri o toplumun sessizliğe ve gürültüye yükledikleri anlamı belirlemektedir. İçe dönük bir toplum şenlik yerine sessiz ayinleri tercih etmesi söz konusu olabilmektedir. Günümüz modern toplumları ise toplumsal törenlerde sessizlik kısmi olarak yer almasına rağmen ses ve gürültünün ağırlı̆̆ı görülebilmektedir.

Genel olarak toplumların gürültü ve sessizliğe yükledikleri anlamlar değişmekle birlikte günümüz toplumlarında gürültü sıradanlaşıp, yaygınlaşmaktadır. Modern dünya sessizliğe yeni anlamlar katmaktadır. Sessizlik sükûnet, huzur, dinlenme gibi anlamlardan sıyrılarak yeni anlamlar içermektedir. Korku, endişe ve kaygı içeren ruh halleri sessizlik ile örtüşmektedir. İnsanların sessizlik karşısında ürperti ve korku duyması insanlara farkına varmadan aşılanmaktadır. Televizyon ya da dijital televizyon kanalları gibi platformlarda yayımlanan dizi film, film ve sinemalarda bu durum karşımıza çıkmaktadır. Özellikle korku içerikli film ve sinemalarda sessizliğin ardından gelen korkunç bir olay veya yaratık sessizliği ürpertiye dönüştürebilmektedir. Böylelikle sessizlik, sükûnetten ziyade ürperti olarak insanların zihnine kodlanmaktadır.

Sessizlik ve gürültünün mekânsal bir boyutu söz konusudur. İnsanların şehrin gürültüsünden uzaklaşırken sessizliğin ürpertisiyle yüzleşmektedir. Şehir dışında oluşturulan yeni yerleşim alanları ile insanlar, gürültüden sessizliğe sığınırken sessizliğin korkusundan sığınacak bir araca veya yönteme ihtiyaç duymaktadır. Bu paradoksal durum içerisinde insan kendini sessizliğin ürpertisinden emin olmak amacıyla çözüm olarak güvenliklerini de sağlamaya yönelmektedir. Güvenlikli siteler, gürültüden uzak bir mekân olarak kabul görülmekte ve insanları sessizliğin endişesinden emin kılmaktadır.

Sessizliğe ve gürültüye yüklenilen anlam, dinsel açıdan farklılaşmaktadır. Bazı dinlerde tanrılar kendilerini gürültülü bir sağanak veya bir fırtına olarak gösterdiği düşünülmektedir. İncil'de Tanrı, genelde sessizliğin kendisidir. Krallar Kitabında Tanrı́nın kendisini İlyas'a nasıl gösterdiği dile getirilir. İlk önce bir kasırga çıkar, arkasında bir deprem olur, akabinde ise yangın çıkar. Tanrı bunların hiçbirinde olmayıp en sonunda sessiz bir uğultu gelir. İncil'deki ifadesi ile "kırılgan bir sessizlik" olarak ifade edilmekte ve Tanrı sessizlik içinde olduğu anlatılır (Kagge, 2020: 72). Kuran'da ise Ad kavmine azap olarak gürültülü bir rüzgârın gönderildiği Kamer süresinde geçmektedir. Gürültünün bir azap aracı olarak Allah tarafından gönderilmesi gürültünün olumsuz bir anlama sahip olduğunu göstermektedir. Bu bağlamda sessizlik ve gürültünün dinsel bir boyunun olduğu anlaşılmaktadır. Dinsel ibadetlerde sessizlik ve huşunun ön planda olması dini açıdan sessizlik anlamlı hale gelmektedir. 
Sessizlik, gürültünün karşısında yer alırken, aynı zamanda dinlemeye verilen önemle bağlantılıdır. Dinlemeye önem veren toplumlar ile günlük yaşamda ile ruhsal faaliyetlerde manevi bir gelenek olarak görülen din veya inançlarda sessizlik gelişir. Dikkatli dinleme, konuşmacı ile dinleyici arasında vuku bulan bir dayanışma türüdür. Doğal olarak konuşmalar sessizlik içerisinde gerçekleşir. Budizm gibi dinsel inançlarda sessizlik ile içsel sessizliğe ulaşma hedeflenir (Petkova, 2015: 12). İslam'da ise içsel sessizlik hal diline tekabül etmektedir. İslam'da dinin tebliği konusunda söz ve davranış boyutu ile gerçekleşmektedir. Söz ile tebliğ, konuşma üzerinden gerçekleşirken davranış ile tebliğ hal dili ile gerçekleşmektedir. Tebliğde hal dili, tasavvuf içerisinde kabul görmüş ve kalbin dile gelmesi olarak anlam bulmuştur. Bu bağlamda hal dilinde susarak ve sessizlik içerisinde gönül dilinin konuşması durumu ortaya çıkmaktadır.

Modernlik, sessizlik konusunda paradoksal bir çerçeve ortaya koymaktadır. Sessizlik az önce değinildiği üzere bir ürpertiye dönüştürülürken bazen de bir bedel karşıllğında kazanabilecek bir olgu olarak lanse edilmektedir. Modernliğin keşmekeşi içinde sessizlik, bedava değil ve artan bir bedeli söz konusudur. Sessizlik, gittikçe talebi artan kit bir șey haline gelirken sessizliğe ricat Hristiyan ya da Budist bir çerçevede kutsalın himayesinde olduğunda, hiper-modern bir hayatın şiddetinden mustarip bir avuç insanın "kendilerini toparladıkları" evlerde bulunabilmektedir (Balandier, 2018: 40). Kutsalın sessizliği ile sekülerin gürültüsü arasında kalan insanlar sükûnet ve huzur için sessizliği tercih etmeleri halinde dini ritüel ve pratiklere yönelebilmektedir. Bazı mabetlerin şehirden uzak, hatta dağ bașlarında, ücra yerlerde bulunması gürültüden ve şehrin keşmekeş hayatından beri olmayı amaçladığını göstermektedir.

Modern dünyanın keşmekeşliği ve gürültüsü bireyi sessizlik arayışına sokabilmektedir. Epstein, sessizliğin, geç dönem orta çağ Avrupası manastırlarında beslendiğini ve büyütüldüğünü ifade eder. Bazı manastır toplulukları konuşmayı caydırır veya yasaklar. Günün çoğu için, el işaretleriyle iletişim kurmak suretiyle seslerini ayinle ilgili ilahilerin kendine özgü formülsel melodilerinde veya sözlü duanın ritimlerinde yoğunlaştırır (2020: 53). Modern dünya, karmaşıklığı, keşmekeşliği ve gürültüsüyle kaotik bir haldedir. Birey bu kaotik durumdan geçici de olsa yalnız kalıp kafasını dinleyebileceği özel bir köşesinin olmasını ister. Bu köşe, evin oluşturduğu büyük tapınağın içerisindeki yeni mahrem alandır. Bu yeni mahrem alan olan 'odam' tabiri orta çağ keşişlerinin hücrelerinin seküler versiyonun bir ifadesi olarak kullanılmaktadır (Carroll, 2008: 86). Modern öncesi dönemin seküler alanı modern dönemin mahrem alanına dönüşmesi dikkat çekmektedir. Münzevi hayatın dünyevi alanı olan şahsi odalar günümüzde modern dünyanın keşmekeşliğinden ve gürültüsünden bir kaçış alanına dönüşmektedir. Bu durum, gürültünün zaman içerisinde mahiyetindeki değişimlere rağmen gürültüden kaçış anlamında insanların bir sığınak aradığını göstermektedir.

Sosyolojik yaklaşım içerisinde gürültü değerlendirilirken sınıfsal farklılıklar da öne çıkmaktadır. Düşük gelirli insanlar ile varlıklı insanlar arasında gürültüye maruz kalma ve gürültü ile yaşama boyutuyla farklılık söz konusudur. Düşük gelirli insanlar genelde işyerlerinde daha çok gürültüye maruz kalırlar. Evlerindeki kötü yalıtım sebebiyle de komşu gürültüleriyle karşı karşıya kalmaktadır. Varlıklı insanlar ise gürültünün daha az ve havanın daha temiz olduğu yerlerde yaşarlar. Arabaları, çamaşır makineleri, bulaşık makineleri vb. daha sessiz çalışırlar. Varlıklı sınıflar genelde daha fazla boş zamanları vardır, daha temiz ve daha sağlıklı yemek yerler. Aslında sessizlik çok az insana daha uzun, daha sağlıklı ve daha zengin bir hayat imkânı sunan bir ayrımın göstergesidir (Kagge, 2020: 61-62). Bourdieu (2015: 122) ise iç mekânlardan hareketle zenginlerin kibirlerini gürültücü, yoksulların sefaletini sessizlik olarak ifade etmektedir.

\section{Modern Dünyada Sessizlik ve Gürültü}

Günümüz dünyası modern dünya olarak adlandırılmaktadır. Modernliğin özelliklerine bakıldığında en önemli yanının yenilik ve süreklilik olduğunu söylemek mümkündür. Yenilik ve süreklilik, modernliğin sürekli yenilenmesine ve sonu gelmemesine işaret eder. Bu yönüyle Habermas'ın modernlik için kullandığı "bitmeyen proje" kavramı haklı çıkmaktadır. Modern dünyada yaşanılan 
gelişmeler geleneksel dönem ile karşılaştırılarak ekonomik, kültürel, siyasi, gündelik hayat vb. alanında ortaya çıkan yenilik ve değişimler olumlu görülürken gelenekselden daha iyi olarak takdim edilmektedir. Bazen bu yeniliklere olumlu anlamlar atfedilirken bazen de yaşanan değişimlerin geçmişle ile mukayesesi neticesinde hayıflanmalara neden olabilmektedir. Teknolojik aygıtların hayatı kolaylaştırması modernliğin olumlu yönlerine işaret ederken sosyal ilişkilerdeki zayıflamalar kişilerde nostaljik bir özlemin oluşmasına ve bugüne hayıflanmasına neden olabilmektedir.

Giddens, modernitenin sanayileşmiş dünyaya karş̧llk gelen döneme işaret ettiğini belirtir. Sanayileşme terimi üretim süreçlerinde maddi gücün ve makinelerin yaygın kullanımını içeren toplumsal ilişkileri anlatmak için kullanılmaktadır. Burada hem rekabetçi ürün piyasalarını hem de işgücünün metalaşmasını içeren bir meta üretimi sistemi olarak anlaşılan kapitalizmdir. Ayrıca sanayileşen toplumda ortaya çıkan ilişkilerin ve buna bağlı olarak gelișen kapitalizmin kontrol edilebilmesi önem arz etmektedir. Gözetim, tâbi nüfusu denetleyici kontrolü anlatır; bu kontrol bazen Foucault'nun kullandığı anlamda "görünür" gözetim biçimini, bazen toplumsal etkinlikleri koordine etmek için bilgilerin kullanılması biçimini alabilmektedir. $\mathrm{Bu}$ durumu, "savaşın sanayileşmesi" bağlamında şiddet araçlarının kontrolünden ayrılabilir. Modernite öncelikle nükleer silahlanmanın göstergesi olduğu silahların potansiyel yıkıcı gücünün daha sınırsız hale geldiği bir "topyekûn savaş" çağının habercisidir (2010: 29). Modernite hem sanayileşme hem de topyekûn savaşa işaret ederken aslında gürültüyü çağrıștırmaktadır. Sanayileşme ile makinelerin gücü ses olarak akseder ve gürültü olarak ortaya çıkar. Savaşın sanayileşmesi ve topyekûn savaş yine gürültüyü ifade etmektedir. Silahların ve bombaların patladığı ortam ve savaş uçaklarının çıkardığı sesler düșünüldüğünde acı bir gürültünün yansıması olarak ifade etmek mümkündür. Ayrıca Bauman (2003: 14) düzen ve kaosu modern ikizler olarak tanımlar. Modernlik, sanayinin ve savaşın getirdiği kaosu gözetim ve kontrol ile düzene sokmaya çalışmaktadır.

Modernlik acı enstrümanlar ile savaşı gerçek kılarken yine bu savaşlardan mülhem oyunlar icat etmektedir. Savaș ve savaş oyunları gürültü ile mücessem hale gelmekte ve gürültü yaşanan acıları örtme işlevini görmektedir. Oyunda kullanılan sesler, savaşın insanların (asker, sivil, kadın, erkek, yaşlı, genç, çocuk), hayvanların ve doğanın yok olmasına sebep olduğu düşüncesi insanların aklına gelmesini engellemektedir. Savaşların bir oyuna dönüşmesi, Baudrilard'ın similiasyon olarak kavramsallaştırdığı duruma işaret etmektedir. Savaşlar gerçek bir oyuna dönüşürken, bu gerçeklik oyun sektörüne ilham vermesinin yanı sıra yaşanılanları ve hakikatleri göz ardı etmesini sağlamaktadır.

Modernliği, kent ve metropoller ile betimlemek mümkündür. Zira modern hayat kentsel alanlarda yaşanmaktadır. Bu alanların bir diğer özelliği kalabalık ve gürültülü olmasıdır. Kentler, metropoller, megapoller trafik ile anılmakta ve trafik-şehirler şeklinde yapılanmaktadır. Kentin dolaşım ağları yoğunlaşırken, kent yeni alanlara taşınarak yayılmaya devam etmektedir. Trafik sıkışmalarına ve yoğunluğuna bağlı tıkanmalar, ortaya çıkan gürültüler, taşıtlardan kaynaklanan kirliliğin bir bileșeni haline gelmektedir (Balandier, 2018: 43). Metropol denildiğinde trafiğin keșmekeşliği ve kornaların 'bağrışmaları' akla gelmektedir. Bu tabloda insanların gürültüye alışması veya gürültü ile yaşamasını bilmesi gerekmektedir. Metropol bireyi trafik gürültüsünü sorun etmeme eğiliminde olup bu şartlar altında yaşamaya alışmaktadırlar.

Modern dünya, kentte tekâmüle ererken, kent kalabalık ve gürültüyle tasavvur edilmektedir. Bu yaklaşımı, modernlik söyleminin pek çok ana metni ve yazarlarında görmek mümkündür. $\mathrm{Bu}$ metinlerde büyük kentin karmaşasını ve geçiciliğini köksüzlük, yersizlik-yurtsuzluk temaları eşliğinde modern hayat ve modernliğin göstergesi olarak ele alınır. Örnek olarak Charles Baudelaire, edebiyatta "Modern Hayatın Ressamı" ("Peintre de la vie Moderne") (1863) adlı makalesinde modernliği "büyük bir hızla değișen bu geçici, ele avuca sığmaz (...)" unsur olarak tanımlar ve kalabalığı modernliğin simgesi ve dünyanın merkezi, sanatçıyı "dünya insanı, kalabalıkların adamı ve çocuk" olarak vurgular (Talu, 2010: 145). Bu çerçevede kent hayatı kalabalık ile tasvir edilirken, kalabalık da gürültüyü ima etmektedir. Zira "kent kalabalığı" denilince 
akla ilk gelenler arasında insan yoğunluğu ve gürültülü bir şehir yer almaktadır. Bu açıdan modern dünya gürültüyü ortaya çıkarmaktadır.

Modern hayat bireye kalabalıkta kaybolma ve gürültü çıkarma imkânları verirken, bu koşullarda bireyin sessizliğe olan ihtiyacını sağlaması gerekmektedir. Birey, sessizliğe ermesi ancak bir kaçış veya izole olma ile gerçekleştirebilmektedir. Bu durum herkese mümkün olmadığı için insanlar genellikle kentin gürültüsünden kaçmak için evinin sessizliğine sığınmaya yönelmek zorunda kalmaktadır. Ancak bu sessizlik de kısmi olarak değerlendirmek mümkündür. Bireyin özel alanı olan evi de kent gürültüsü kadar olmasa da gürültüye maruz kalmaktadır. Evini kentin gürültüsüne kapatan birey, modern dünyanın gürültüsüne mahkûm olabilmektedir. Burada birey, televizyon ve internet ile modern dünyaya bağlı kalmak suretiyle evini dışarıya izole edememekte ve kendisini inzivaya çekememektedir.

Geleneksel kent ve sanayisi ile kıyaslandığından modern kent ve sanayisi daha gürültülüdür. Bu gürültülü hal artmaya devam etmektedir. Balandier (2008: 39)'in belirttiği üzere Fransa'da kamuoyu yoklamaları, halkın belli başlı sıkıntıları sıralamasında gürültüyü ilk sırada göstermektedir. Gürültünün rahatsız edici ve sıkıntı edici özelliklerine rağmen modern kentlerde insanlar gürültü ile yaşamaya devam etmektedir. Gürültüye verilen cezaları modernliğin kaos ve düzen özelliklerine bağlamak mümkündür. Modern dünya gürültülü bir dünya olup bu durum dünyada kaosa neden olurken gürültüye getirilen kısıtlama ve cezalar düzenin tahkim edilmesini amaçlamaktadır. Modernlik gürültülü olup zaman zaman gürültüye ceza vererek bazen sessizliği ister gibi görünmektedir.

\section{$4 \quad$ Popüler Kültürde Sessizlik ve Gürültü}

Popüler kültür üzerine zengin bir literatür olmasına rağmen tartışmalı bir alan olmaya devam etmektedir. Popüler kültürün ne olduğu ile ilgili kısa bir girizgâh konunun anlaşılması için faydalı olacağı düşünülmektedir. Bir toplumda geniş bir şekilde paylaşlan inanç ve pratikler popüler kültür kapsamında değerlendirildiği gibi hem halk inançları, pratikleri hem de popülerleştirilmiş seçkin kültürel biçimleri popüler kültürün muhtevasında yer almaktadır. Buradan hareketle halk kültürü ile yüksek kültürünün etkileşiminden popüler kültürün özgül bir yapısı ortaya çıkmaktadır (Mutlu, 2012: 27-28). Popüler kültür, genel ve yaygın inançları ve popüler seçkin kültürü yansıtabilen farklı bir dinamiğe sahiptir. Popüler kültür aslında popüler olmasından hareketle muteber olanla değil, rağbette olanla ilişkilidir. Bu bağlamda muteber popüler kültür, gündelik hayat ile ilişkili olup gündelik hayat bilgisine diğer kültürlerden daha fazla bel bağlar (Sözen, 2012: 59).

Genel anlamda popüler kültür, herhangi bir toplumun, herhangi bir zamandaki egemen kültürü şeklinde anlamlandırılmaktadır (Sözen, 2012: 64). Toplumdaki yaygın ve hâkim düşünce ile pratikler toplumun popüler kültürünü oluşturmaktadır. Mutlu (2012: 32)'nun ifadesiyle "bu kültür, en kötü biçiminde hayatın en düşük, en kaba, en önemsiz veçhelerinin yankılandığı bir mekândır; en iyi biçimde ise hayatın karmaşıklığına, soyluluğuna ve hikmetine seslenir". Burada oluşturulan popüler kültürün farklı veçhelerine dikkat çekilmektedir. Diğer taraftan gittikçe her şeyin birbirine benzediği merkezileşme sürecine dikkat çekilmektedir. Erdoğan (2012: 76) kültür endüstrisi sürecine dikkat çekerek kitle üretim endüstrileri tarafından üretilen ürünlerin, yaygın kullanım anlamının dönüşerek kapitalizmin lehine dönüşüme uğratıldığını ifade eder. Popüler kültür bu yönüyle insanların gündelik hayatlarını etkileyerek kapitalizmin yayılmasına imkân vermektedir. Popüler kültür, kitle iletişim araçları, radyo, sinema ve müzik alanlarındaki etkisiyle insanların yemelerine, içmelerine, giyimine, konuşmalarına kısaca gündelik hayattaki pratiklerine sirayet edebilmektedir.

Popüler kültür, gençlere ve yaşlılara farklı şekilde yaklaşarak onların duygularını etkisi altına alabilmektedir. Turner (2017: 117-118)'in ifade ettiği gibi aşk, cinsel doyum ve gençlik paradigması ile popüler kültür genç kuşakları etkilemektedir. Diğer taraftan popüler kültür, aşka ve romantik bağlılığa sahip olmayı ya da bu bağlılıklarını sürdürebilmek için yaşlanmaktan kaçınabilmeyi uman 
daha yaşlı jenerasyonları etkileyecek kadar da güçlüdür. Yaşlılara yönelik romantik aşkı devam ettirmelerinin teşviki söz konusu iken gençlere yönelik olarak popüler müzik yoluyla tüketim ve aşk karmaşasına sürüklendikleri bir aşkı teşvik etmektedir.

Günümüz dünyası gürültülü bir dünya olması nedeniyle gençler gürültülü bir dünya içinde doğmaktadır. Ayrıca gençler mekânsal olarak kendi ortamlarını oluşturmaktadır. Hareketlilikleriyle makine ve hız arasında bir tutku oluşturmaktadır. Görüntü üretme pratiğiyle, makinasal yoğun müzikle, özel efektlerle ilgili muhtelif beceriler edinmektedirler (Balandiers, 2018: 43). Gençlerin gürültü ile haşir neşir olması ve sürekli görüntü, ses ve hareketliliklerinde gürültülü olma hali söz konusu olmaktadır. Dinlenilen müzikler hem desibel açısından hem de içerik açısından oldukça gürültülü olup gürültüyü teşvik etmektedir. İzledikleri ya da çektikleri görüntüler de aynı şekilde bir gürültü pratiği oluşturduğunu söylemek mümkündür.

Popüler kültürün müziğe yansıması ile popüler müzikler ortaya çıkmaktadır. Popüler müzik gittikçe çoksesli ve elektronikleşmesi sonucunda gürültülü bir yapıya bürünmektedir. Popüler müziğin özellikleri arasında standartlaşma ve rutinleşme özellikleri yer almaktadır. Adorno'ya göre endüstrileşmiş popüler müzik dinleyicilerini etkilemesinde bu özellikler etkili olmaktadır. Standartlaşan ve rutinleşen popüler müziğin içinde dinleyici kaybolmaktadır. Ayrıca popüler müziğin ürettiği haz yapay, geçici ve sahtedir. Popüler müzik dinleyicisi "ritmik olarak itaatkâr" olarak görülmektedir. Dinleyici şarkının standartlaştırılmış ritmini takip ederek ve onun tarafından koşullandırılarak "ritmin kölesi" olmaktadır (Kuyucu, 2016: 193). Adorno ve Horkheimer (2010: 125) çoksesli müziğin içkin olarak çoğulculuğa işaret ettiğini ve kolektif ilişkilerini etkilediği ifade eder. Müzik yoluyla cemaate entegre olanlar, ona itaat etme zorunluluğunu hisseder.

Günümüz popüler müziğin iniş olarak adlandırılan kısma kadar, daha uzun süreli bir çıkıştan oluşan giriş kısmı oldukça sessizdir. İşte orada davullar ve şarkının önemli konusu ortaya çıkar. Daha sonra tekrar sessizleşir ve tekrar ses artar. Bu şekilde yinelenerek zıtlıkları seven beyni uyanık tutar. Ses atmosferi değiştiğinde beyin uyanır ve her şey monotonlaştığında uyuklamaya başlar. DJ'ler aslında bu zıtlıkları kullanarak ilgi uyandırmaktadır. Önce bir iki ölçü sessizlik ve yüksek frekanslı ses patlaması ile çok ve az olan arasındaki zıtlık beyni etkilemektedir (Kagge, 2020: 92). $\mathrm{Bu}$ zıtlıklar üzerinden meydana gelen gürültüye dinleyiciler itaat etme hissine kapılmaktadır.

Popüler kültürde ve popüler kültürün ürünlerinde gürültünün onaylandığı ve yaygınlık gösterdiği düşünülmektedir. Popüler kültürün insanların sürekli bir hareketliliği aşılarken aynı zamanda duygusal olarak onları popüler kültürün ürünlerini talep etmeye müsait hale getirmektedir. Popüler müziğin yapısı açısından gürültülü olduğunu ifade etmek mümkündür. Müziğin sesten uzaklaşarak daha çok makineleşmesi ve seslerin de makineden geçirilmesi sonucu popüler müzikte gürültü artmaktadır.

\section{$5 \quad$ Her Yerde Gürültü: Müzik}

Gürültü genellikle huzursuzluk, öfke, kavga ve şiddet gibi olumsuz şeylerle bağdaştırılmasına rağmen zihni çelen dikkat dağıtıcı sesler olarak zihnimize kodlarız. Ne kadar çok rahatsız edilirsek dikkatimizin dağıtılmasını da o kadar isteriz (Kagge, 2020: 46). İnsanların modern hayatın zorluk ve sıkıntıların üstesinden gelemese de sorunlara bir mola vermeyi düşünmektedir. Çalışmak kadar tabii olan dinlenmeye, meşakkatli durumlarda ve zamanlarda da ihtiyaç duyulmaktadır. Zorluklar insan zihnini yorması açısından "kafa dağıtma" adına birey, farklı düşünsel ve duygusal yönelimleri çözüm olarak görebilmektedir. Burada "kafa dinleme" ya da "kafa dağıtma" olarak müzik dinleme alternatif bir çözüm olarak kabul görmektedir. Aslında insanların farklı amaçlarla farklı müzik türlerine yönelmesi gürültü ve sessizlik arasındaki tercihini de göstermektedir. Müzik türlerindeki farklılıklar ritim ve enstrüman ile ilgilidir.

Müzik parçalarının özellikleri kişilerin hâletiruhiyesini etkileyebilmektedir. Bazı müzik parçalarının sakinleştirici bir etkisi olabilirken bazılarının canlandırıcı hatta bazılarının da sinir bozucu etkisi olabilmektedir (Winter, 2018: 14). Müzik türleri insanların duygularını etkilemekle birlikte birey, 
kendince bir müzik zevki oluşturabilmektedir. Müzik türleri insanlara farklı seçenek olarak sunulmakta ve insanlar kendi tarzlarını bu seçeneklere göre oluşturabilmektedir. Bireyin kendisine göre bir tarz belirleyebildiği gibi hâletiruhiyesi ve sosyal koşulları da belirleyebilmektedir. Ayrıca müziğin de fail olarak birey üzerinde etkisi olabilmektedir. Müziğin çıkardığı ses ve oluşturduğu ritim bireyin bedensel ve ruhsal olarak bir hareketlilik yaşamasına neden olabilmektedir. Müziğin tarihte tedavi edici bir yöntem olarak hastalara uygulanması birey üzerindeki etkisini açıç̧a göstermektedir.

Yirminci yüzyılı en iyi tanımlayan seslerden biri fon müziğidir. Fon müziği, alışveriş merkezlerinde, kafelerde, bürolarda, otel lobilerinde ve asansörlerde duyulan ve modern kent hayatının bütünleyici bir parçası olmaya başlandı. Hem banal ve kullanılıp atılabilir bir ses, hem de daha fazla şey satın alıp daha fazla çalışmaya sevk etmek için tasarlanan bir sestir. Pek farkında olmadığımız sesler bedenlerimiz ve zihinlerimiz üzerinde önemli etkilerde bulunabilir. Geçmişte bu özellik, uyumlu avlanmaya teşvik etmek için, birbirimize kenetlenmek ya da dinsel bir huşu duymamızı sağlamak için kullanıldı. Son yüzyılda ise, müzik, enerjimizi ve ruh halimizi iş dünyasına hizmet edecek biçimde denetlemek için bir araca dönüştü (Hendy, 2016: 282-283).

Gürültü müziği olarak bir müzik türünün varlığı, gürültünün müzikte işlevsel olduğunu göstermektedir. Klett ve Gerber (2014: 287) gürültü müziğin performans boyutuna dikkat çekerek, müzik dilini genişlettiğini ifade etmektedir. Aslında gürültünün kaotik, belirsizlik ve saldırganlığına karşın estetik açıdan müziğin harmonisi, uyumu ve yankısı bir araya gelerek belirsizliği oluşturmakta ve performans olarak çekici kılmaktadır. Bu paradoksal durum, tüketim alanlarında, eğlence dünyasında işe yarar olduğu anlaşılmaktadır. Eğlence aracı olarak müziğin kullanılması ve bu durumun sektörel olarak yaygınlaşması müzikte gürültüyü profesyonelce kullanımı ile ilgilidir. Eğlence mekânları modern hayatın bir parçası olarak lanse edilmekte ve insanlar bu mekânlarda gürültülü müzik eşliğinde eğlenmektedir.

Modern dünyanın üretim, tüketim, çalışma, savaş, oyun vb. birçok farklı alanlarında gürültü önemli bir işlev üstlenmektedir. Popüler kültür ürünlerinde ve özellikle popüler müzikte insanlar üzerinde etkisi düşünüldüğünde işlevsel olduğu anlaşılmaktadır. Modern dünyada müziğin işlevsel olarak en üst perdeden kullanıldığını söylemek mümkündür. İnsanlara daha anne karnında müzik dinletilmesi gibi dünyaya gelmeden müzik ile tanıştırılması önerilebilmektedir. Hangi müziğin hangi ruh halinde dinleneceğinden üretim verimliliğinin artışına kadar müzik kullanılmaktadır. Hatta hayvanlardan elde edilecek ürününün artması için hayvanlara bile müzik dinletilebilmesi kabul görmektedir.

\section{$6 \quad$ Kişilerarası İlișsilerde Bir İletișim Tarzı Olarak Gürültü}

Gürültünün insanlar üzerinde farklı etkiler olmakla birlikte insan ilişkilerine de yansıması olmaktadır. Kişilerarası ilişkiler sosyal iletişim ve etkileşim bağlamında gelişirken burada gürültünün farklı veçheleri ile ele almak mümkündür. Gürültünün sosyal ilişkilere olumsuz etkisi olmasına rağmen bazı kimselerin gürültüyü bir iletişim tarzı olarak sergilemesi de söz konusudur.

Kişilerarası ilişkilerin muhteviyatına göre iletişim tarzları ortaya çıkmaktadır. Samimi ilişkilerde iletişim kanalları açık olarak etkileşim gerçekleşmektedir. İnsan ilişkilerinde bireysel farklılıklar da iletişimi ve etkileşimi belirleyebilmektedir. Lider özelliklerine sahip bireylerin iletişimin ve ilişkinin yönü konusunda aktif rol oynayabilmektedir.

İnsanların bireysel farklılıkları iletişim tarzlarını etkilemektedir. Kişilerin içe dönük ya da dışa dönük olmaları onların gürültüye yaklaşımlarını belirlemektedir. Bazı çalışmalar, dışadönüklüğü gürültü rahatsızlığına aracılık eden bir etken olarak göstermektedir. Burada bireyin dışadönüklüğü sosyalliği ile ilgili olup ilgi odağı olmasına da işaret etmektedir. Dışadönük bireylerin sosyallikleri onları duyusal yoksunluğa tahammülsüz kılmaktadır (Jones, Chapman ve Auburn, 1981: 45). Dışadönük birey, sessizliği talep etmez, gürültüyü tercih eder. Burada bireyin gürültüyü içselleştirirken seslerini etkili kullanarak sosyal ilişkilerde etkin olmaya çalıştıklarını söylemek 
mümkündür. Adeta ne kadar çok ses çıkarırsan o kadar etkili olursun mantığı ile sosyal ilişkilerde baskın karakter olabilmektedir. Böyle bir iletişim tarzını tercih eden birey, olumsuz durumlarını örtmek için ses tonlarını ve gürültülü konuşmalarını kullanmaktadır. Böylelikle haksız bir durumda olmasına rağmen bu gürültülü iletişim sayesinde haklı olabilmeyi başarabilmektedir. Bu durum modern dünyada gürültünün baskınlığının modern bireyin iletişim ve etkileşim tarzına yansıması olmakta ve bu tarz bir iletişimin gelişmesine neden olmaktadır.

Dışadönük bireyler sessizlikten ziyade gürültüyü tercih etmektedirler. Ayrıca dışadönük bireylerin sosyal olmaları girişken olmalarını sağlamaktadır. Girişken davranışlar sergilerken özgüvene sahiptirler. Hartley (2010: 309) girişken davranış özelliklerini açık ve anlaşılır ifade, kuvvetli ve akıcı konuşma ile irtibatlandırmaktadır. Dışadönük, girişken ve özgüven gibi özellikler kişilerarası ilişkilerde baskın karakter olabilmektedir. Bu özelliklerle birlikte gürültülü kişiliklerin bireyin sosyal ilişkilerinde başat aktör olmasını sağlamaktadır.

Gürültü, iletişim kanallarında bir bariyer olarak ortaya çıkabilmektedir. Çalışma koşullarında yüksek desibelli yerlerde çalışan insanların kendi aralarında iletişim kurarken gürültünün bariyerini aşmak için jest ve mimiklere başvurmaktadır. Burada duruş, el, kol hareketleri, yüz ifadeleri konuşmanın tamamlayıcı unsurları olmaktadır (Jones, Chapman ve Auburn, 1981: 54). Konuşulurken duyulan gürültü, konuşmayı perdeleyebilmekte ve sözün serencamını bozabilmektedir. Yüksek gürültü ile yașanılması ve bu durumun süreklilik kazanması gibi durumlarda bireyler, iletişim kanallarının tıkanmaması gayesi ve sözü desteklemek, eksik duyulanları tamamlamak amacıyla jest ve mimiklere başvurabilmektedir. Ayrıca bu durumun kalıcı bir iletişim tarzına dönebilmesi olasılı̆̆ güçlenmektedir. İletişimin kesilmediği ve hatta sessiz bir ortamda konuşmalar jest ve mimikler ile yapılması bu durumun alışkanlığa dönüştüğünü göstermektedir.

\section{$7 \quad$ Sağduyu Bariyeri Olarak Gürültü}

Psikologlar yarım yüzyılı aşkın bir süredir gürültü ve insan performansı arasındaki ilişkiyi incelemiş olsalar da, gürültünün kişilerarası davranış üzerindeki etkisi henüz son zamanlarda ilgi konusu olmuştur. Gürültüyü kiş̧ilerarası davranışla ilişsilendiren araştırmalar, dikkat dağıtıcı arka plan seslerinin ses seviyeleri ve kişinin bașkalarına karşı duyarlılığı, özellikle gürültü maruziyeti sırasında ve hemen sonrasında yardım etme istekliliği, ses seviyesinin diğer sosyal davranışlar üzerindeki etkilerini (saldırganlık, kişilerarası çekim, kişilerarası önyargılar vb.) Ele almıştır (Cohen ve Scapacan, 1984: 221).

Gürültünün birey ve sosyal ilişkileri etkilemesinin sosyal boyutu da önem arz eder. Gürültünün, sosyal davranışlar üzerinde olumsuz etkilere sahip olabilmektedir. Trafik gürültüsünün insan davranışı üzerinde etkisini konu alan bir çalışmada bu durum görülmektedir. Appleyard ve Lintell (1972) trafik gürültülerini ölçmek suretiyle "ağır", "orta" ve "hafif" olarak sınıflandırdıkları üç farklı sokak belirlerler. Gürültünün bu sokaklarda yaşayanlara etkileri incelenir. Bu araștırma sonucunda hafif gürültülü olan sokakta yaşayanların ağır gürültülü sokakta yaşayanlara oranla iki katında bir sosyal ağa sahip oldukları ortaya çıkar. Ayrıca gürültülü alanlarda yaşayanların okuldan kaçma, arananlar listesinde yer alma gibi daha çok sorunlar yaşadığı ifade edilir (Jones, Chapman ve Auburn, 1981: 48). İnsanların sahip olduğu sosyal ağların genişliği gürültülü alanlar ile negatif bir ilişkisi olduğu görülmektedir. Sosyal ağlar insanların seçimlerine, hareketlerine, düşüncelerine, hislerine ve isteklerine hem belirli belirsiz hem de çarpıcı bir etkisi olmaktadır (Christakis ve Fowler, 2012: 17). Sosyal ağların hayatımızdaki etkisi ile gürültünün sosyal ağlara etkisi düşünüldüğünde gürültünün sosyal hayatımızı olumsuz etkilediği anlaşılmaktadır. Sosyal ağlar insanlara sosyal destek sağlamaktadır. Sosyal destek kaynakları fazla olan insanlar daha mutlu olmanın yanı sıra olumlu duygu, düşünce ve davranışlara da sahip olurlar. Gürültünün aslında insanların bilişsel, duyusal, duygusal ve eylemsel olarak hayatlarını tesiri olmaktadır. Gürültülü alanlarda yaşama, insanların iyilik eylemlerini dahi belirleyebilmektedir. 
Yüksek yoğunluklu gürültüye maruz kalmanın küçük iyiliklerin gösterilmesi üzerindeki etkilerine ilişkin Korte ve arkadaşları (1975), yaptıkları çalışmada yüksek veya düşük çevresel girdilere sahip olarak karakterize edilen kırsal ve kentsel alanları belirlemek için ses seviyesinin yanı sıra trafik sayımı, yaya sayısı ve görünür 'kamu' binalarının sayısını kullandı. Üç alanda yardımseverlik ölçüsü kullanıldı: bir sokak mülakatı talebine yanıt vermek, anahtarını düşüren birisine anahtara dikkat çekmek ve ellerinde haritalar ile yolunu şaşırmış birine yardım etmek. Burada düşük girdili bölgelerdeki insanlar, yüksek girdili bölgelerdeki insanlara göre bir mülakat verme ve konfederasyona yardım sunma olasılıkları daha yüksektir. İşbirlikçinin dikkatini anahtara çağıran yayaların yüzdesi, düşük girdi alanlarında daha yüksek olmasına rağmen, fark istatistiksel olarak anlamlı değildi (Cohen ve Scapacan, 1984: 222). Burada dikkat çeken husus, gürültü ortamlarda yaşayan insanların bazı duyarlılıklarını kaybetmesidir. Gürültünün basit yardımların yapılmasında bile olumsuz bir etkiye sahip olduğu görülmektedir. İnşaların yardım etme ve iyilikte bulunma hali, gürültü ortamlardan etkilenmektedir. Bu çerçevede sessizlik ve sükûnet, insanların sağduyusunu olumlu yönde etkileyerek yardım etme ve iyilikte bulunma gibi erdemli davranışlara yönlendirebilmesi durumunu ortaya çıkarmaktadır. Balandier'in (2018: 43) belirttiği gibi gürültü bireyin psikolojik direncini kırmaktadır.

İnsanlar, gürültü ile yaşamak zorunda kalması hayat standartlarını olumsuz yönde etkilemektedir. Ancak modern hayat gürültü ile yaşamayı zorunlu kılmaktadır. Fromm (1994) 20. yüzyılda insanların karakteristik özellikleri göz ardı edilemeyecek bir pasiflik içinde olduğunu ve modern endüstri toplumu kendine ve çevreye yabancılaşan, robot haline gelen insanı yarattığını ifade etmektedir. Günümüz insanın pasifliğini gürültü çerçevesinde değerlendireceksek insanlar gürültüye maruz kalırken duyarsızlaştığını ve etrafında olan bitenden bihaber olduğunu veya duyusal ve duygusal yoksunluk içerisinde kaldığını söylemek mümkündür.

\section{Sonuç}

Gürültü, bireylere ve toplumlara etkileri bağlamında sosyal bir olgu olarak karşımıza çıkmaktadır. Bunun yanı sıra gürültüye yüklenilen anlamların da toplumlar arasında farklılıkların olması gürültünün sosyal bir olgu olduğunu göstermektedir. Bu çerçevede toplumlara etkisi ve toplumlarca yüklenilen anlam çerçevesinde gürültü sosyolojinin ilgi alanına girmektedir. Ayrıca bazı insan faaliyetlerinin (çalışma, müzik üretme, hareket etme) gürültüye sebep olması ve gürültünün de insanları olumlu ya da olumsuz etkilemesi, bu olgunun sosyolojik bir zeminde değerlendirebilmeyi mümkün kılmaktadır.

Modern toplum aynı zamanda endüstriyel toplum olarak adlandırılmaktadır. Fabrikalar, ulaşım araçları (uçak, tren, motorlu taşıtlar vb.) ve iletişim araçları endüstriyel toplumunun vazgeçilmezleridir. Fabrikadaki makinelerin, ulaşım araçların çıkardıkları sesler gürültü olarak modern hayatın bir parçası haline gelmektedir. Modern dünyanın tecessüm ettiği kentlerde sessizliğin sağlanması imkân dâhilinde olamazken gürültü kaçınılmaz bir hal almaktadır.

Bireysel ve toplumsal hayatta müzik farklı şekillerde karşımıza çıkarken sessizliği bölen bir işleve de sahiptir. Popüler kültür ile bu kültürün bir ürünü olan popüler müzik ve genel olarak insan hayatında farklı şekillerde yer alan müzik zaman zaman bir gürültü halini alabilmektedir. Müzik içerisinde gittikçe yer bulan gürültü, müziğin yapısını da değiștirmektedir. Müziğin elektronikleşmesi ile birlikte sesin yerini gürültü alırken, ritim bedeni harekete geçiren bir işleve sahiptir. Ayrıca burada gürültü, tetikleyici olmak suretiyle insanları duygusaldan ziyade duyusal olarak etkilemektedir. Modern toplumda verimliliğin artması ve tüketimin cazip kılınması amacıyla müzik elverişli bir enstrümana dönüşebilmektedir. Bireyler müzik eşliğinde çalıștırılarak onların performanslarının artması sağlanırken maksimum verimlilik amaçlanmaktadır. Aynı şekilde bireylerin tüketime yönelmesini sağlamak amacıyla reklamlarda müzik kullanılmaktadır. Ayrıca AVM ya da mağazalarda yüksek volümlü müzik eşliğinde insanların kendilerinden geçercesine daha fazla tüketime yönelmeleri teşvik edilmektedir. 
Gürültü, sosyal ilişkiler içerisinde farklı boyutlarda yer almaktadır. Kişilerarası ilişkilerde her bireyin farklı bir üslup ve iletişim tarzına sahip olması sessizlik ve gürültünün iletişimde kullanılmasına neden olabilmektedir. Bireyin sessizlik ve gürültüye karşı duyarlılığı onun kişilik özellikleri ile de ilişkilidir. Bireyin dışa dönük olması onların iletişim tarzlarında gürültünün etkin olmasına neden olmaktadır. Bir iletişim tarzı olarak gürültü bireyin retoriğini inşa etmesine ve diğer insanlara tahakküm kurmasına neden olabilmektedir. Yüksek volümlü ses tonları ile karşıdaki bireyi sindirebilmektedir. İçe dönük bireyler sessizliği tercih ederken, dışa dönük bireyler sessizliğe tahammül gösterememektedir.

Gürültü ve sessizlik insan hayatının standartlarını etkilerken aynı zamanda onların duyusal ve duygusal olarak da etkilemektedir. Başka bir ifade ile gürültüye maruz kalan insanların hayat standartları gürültüden olumsuz etkilenmektedir. Gürültü seviyesi yüksek yerlerde yaşayan insanların sosyal ağlarının, daha sessiz alanlarda yaşayanlara oranla daha dar olduğu anlaşılmaktadır. Duyusal ve duygusal açıdan gürültünün insanları duyarsızlaștırmaktadır. Gürültülü alanlar, insanların duyularını ve duyarlılıklarını olumsuz etkilemektedir. Buna göre gürültülü alanlarda yaşayanların yardım etme, iyilikte bulunma vb. olumlu davranışlarının sessiz alanlarda yaşayanlara göre daha az olduğu ifade edilmektedir. Bu çerçevede gürültü, sosyal çevremizin oluşumunu ve sosyal duyarlılığımızın düzeyini etki ederek sosyal ağlarımızı sınırlandırabilmekte ve yardım etme ile iyilikte bulunma gibi sağduyulu davranışlarımızı da törpüleyebilmektedir.

Sonuç olarak sosyal bir olgu olan gürültü hayatımızda yer almaktadır. Gürültünün, modern dünyanın bir paradoksu olduğunu ona yüklenilen anlamlara bakarak da anlamak mümkündür. Modern dünya bir taraftan gürültüyü artırırken diğer taraftan gürültünün neden olduğu olumsuzlukları kabul etmektedir. Gündelik hayatın her alanında gürültü ile insan yönlendirilmektedir. Bunun yanı sıra gürültü bir iletişim tarzı olarak insan ilişsilerinde de belirleyici olabilmektedir.

Hakem Değerlendirmesi: Dışbağımsız.

Finansal Destek: Yazar bu çalışma için finansal destek almadığını beyan etmiştir.

Peer-review: Externally peer-reviewed.

Grant Support: The author received no financial support for the research, authorship, and/or publication of this article.

\section{Kaynakça/ References}

Adorno T. ve Horkheimer, M. (2010). Sosyolojik açılımlar. (M. S. Durgun ve A. Gümüş, Çev.). Ankara: Bilgesu Yayınları.

Balandier, G. (2018). Büyük rahatsızlık (D. Çetinkasap, Çev.). İstanbul: Türkiye İş Bankası Kültür Yayınları.

Bauman, Z. (2003). Modernlik ve müphemlik (İ. Türkmen, Çev.). İstanbul: Ayrıntı Yayınları.

Bourdieu, P. (2015). Ayrım (D. Fırat ve G. Baykurt, Çev.). Ankara: Heretik Yayınları.

Berman, M. (2016). Katı olan her şey buharlaşıyor (Ü. Altuğ ve B. Peker, Çev.). İstanbul: İletişim Yayınlarl.

Carroll, J. (2008). Benlik ve ruh: Modern Batı́nın anlam arayışı (İ. Durdu, Çev.). İstanbul: Etkileşim Yayınları. 
Christakis, N.A. ve Fowler, J.H. (2012). Sosyal ağların şaşırtıcı gücü (D. Yüksel, Çev.). İstanbul: Varlık Yayınlarl.

Cohen, S. ve Spacapan, S. (1984). The social psychology of noise. D.M. Jones ve A.J. Chapman, (Ed.), Noise and Society içinde (ss.221-245). Chichester, UK: Wiley.

Epstein, M.J. (2020). Sound and noise. London: McGill-Queen's Press.

Erdoğan, İ. (2012). Popüler kültürde gasp ve popülerin gayri meşruluğu. Doğu Batı Dergisi, (15), 69102.

Fromm, E. (1994). Erdem ve mutluluk: Ahlak psikolojisi üzerine bir deneme (A. Yörükan, Çev.). İstanbul: Türkiye İş Bankası Kültür Yayınları.

Giddens, A. (2010). Modernite ve bireysel-kimlik: Geç modern çağda benlik ve toplum (Ü. Tatlıcan, Çev.). İstanbul: Say Yayınları.

Güler, Ç. ve Çobanoğlu, Z. (1994). Gürültü. Ankara: Sağlık Bakanlığı Çevre Sağlığı Temel Kaynak Dizisi, No:19.

Hartley, P. (2010). Kişilerarası iletişim (Ü. Doğanay, M. A. Yamanoğlu, B. Şimşek, P. Özdemir, H. K. Şanlı ve İ. Ö. Taştan, Çev.). Ankara: İmge Kitabevi.

Hendy, D. (2016). Sesin beşerî tarihi (Ç. Çıdamlı, Çev.). İstanbul: Kolektif Kitap.

Jones D.M., Chapman, A. J. ve Auburn, T.C. (1981). Noise in the environment: A social perspective. Journal of Environmental Psychology, (1), 43-59.

Kagge, E. (2020). Gürültü çağında sesizlik (N. Bakar-Langeland, Çev.). İstanbul: Alfa Yayınları.

Klett, J. ve Gerber, A. (2014). The meaning of indeterminacy: Noise music as performance. Cultural Sociology, 8 (3), 275-290.

Kuyucu, M. (2016). Theodor W. Adorno'nun perspektifinden popüler Türk müziğinde standartlaşma sorunsalı. TRT Akademi Dergisi, 1/1, 188-208.

Mutlu, E. (2012). Popüler kültürü eleştirmek. Doğu Batı Dergisi, (15), 11-44.

Petkova, D.P. (2015). Beyond silence. A cross-cultural comparison between finnish 'quietude' and Japanese' tranquility'. Eastern Academic Journal, (4), 1-14.

Sözen, E. (2012). Popüler kültür retoriği: Sahiplik içinde yokluk ve sağduyu bilgisi. Doğu Batı Dergisi, (15), 57-69.

Talu, N. (2010). Modernlik söylemi: Endişeli bakışlarda modern birey. METU JFA, 27 (2), 141-171.

Turner, B.S. (2017). Din ve modern toplum (A. Tüfekçi, Çev.). İstanbul: Sentez Yayıncılık.

Winter, E. (2018). Akıllı hissetmek duyularımız neden düşündüğümüzden daha rasyoneldir? (P. Onur, Çev.). İstanbul: İstanbul Bilgi Üniversitesi Yayınları.

Zafer, C. ve Vardarlıer, P. (2019). Toplumsal gürültüden toplumsal hareketlere sosyal medyanın rolü: Arap Baharı ve Gezi Parkı olayları örneği. Afyon Kocatepe Üniversitesi Sosyal Bilimler Dergisi, 21(2), 379-390. 